\title{
Petroleum: From Basic Features to Hydrocarbons Bioremediation in Oceans
}

\author{
Edmo M. Rodrigues*, Marcos R. Tótola* \\ Laboratório de Biotecnologia e Biodiversidade para o Meio Ambiente, Departamento de Microbiologia, \\ Universidade Federal de Viçosa, Viçosa, Brazil \\ Email: "edmomontes@yahoo.com.br, "totolaufv@gmail.com
}

Received 28 October 2015; accepted 12 November 2015; published 17 November 2015

Copyright (C) 2015 by authors and OALib.

This work is licensed under the Creative Commons Attribution International License (CC BY).

http://creativecommons.org/licenses/by/4.0/

(c) (i) Open Access

\begin{abstract}
This review provides a general overview of petroleum characteristics and bioremediation strategies applications in oceanic environments contaminated with petroleum hydrocarbons during exploration and transportation processes offshore. The vast oil reserves in the offshore fields have been explored for the production of light and heavy oil. The hydrocarbons exhibit very different physicochemical characteristics including those of hydrophobicity, molecular weight, melting and boiling points, toxicity and recalcitrance. This review is to highlight the basic oil characteristics, and to reveal the manner in which accidents can occur resulting in oil spills in the sea. We focus on hydrocarbon degradation through the application of bioremediation techniques, because this is considered more advantageous economically compared with the physical or chemical remediation techniques, as well as being more effective in contaminant removal. This study provides knowledge about strategies that can be applied in accidents involving oil spill on the ocean and thus boosts oil spill cleanup technology and lowers the environmental risks of offshore management of activities with petroleum.
\end{abstract}

\section{Keywords}

Bioremediation, Biostimulation, Bioaugmentation, Hydrocarbon Degradation, Oil Spill

Subject Areas: Biodiversity, Biotechnology, Ecology, Environmental Sciences, Marine Biology, Microbiology, Oceanology

\section{Characteristics and Properties of Petroleum}

Petroleum, occurring as deposits in sedimentary rocks across the world, is made up of a mixture of solid, liquid and gaseous compounds. From the chemical perspective, oil is a complex combination of hydrocarbons, com-

"Corresponding authors. 
posed of hydrogen and carbon atoms [1] [2]. Besides hydrocarbons, satisfactorily small amounts of nitrogen compounds, oxygen and sulfur, as well as traces of certain metals can also be found [3].

Normally, the thousands of chemicals found in the crude oil are separated out by fractional distillation to produce different by-products that are important in industrial use.

As petroleum fuels meet nearly half the global energy demands [2], oil is one of the most important and widely used substances in human activities. Modern societies have, therefore, for many decades, until today, rated it highly, a state of affairs that is likely to continue for several more years, until alternative energy resources become economically viable [4] [5].

Several theories have been proposed for the presence of oil on the planet. The most accepted theory supposes that oil is formed from the deposits of organic waste, chiefly plankton, at the bottom of lakes and seas, through chemical and physical transformations over thousands of years [6]-[8]. Most of the petroleum currently available originated through diagenesis, a process involving the subjection of organic material to a wide range of physical and chemical changes under temperature ranges between $50^{\circ} \mathrm{C}$ and $60^{\circ} \mathrm{C}$, and the catagen phase, in which the organic substance undergoes thermal changed between $175^{\circ} \mathrm{C}$ and $200^{\circ} \mathrm{C}$ [9] [10].

\subsection{Physical Chemistry Composition}

Petroleum comprises thousands of hydrocarbons, containing chains of carbon and hydrogen molecules, in solid, liquid or gaseous forms. Under conditions of ambient temperature and pressure, petroleum generally occurs in the liquid form [3]. A small percentage of nitrogen, sulfur and oxygen molecules, besides organometallic compounds, are also found [2] [11].

The nonpolar hydrophobic hydrocarbon compounds [12] constitute the oil, as well as plants and animals [13]. A wide range of combinations of the molecules of carbon and hydrogen oil with different molecule sizes and structural conformations result in different molecular weights [1].

At ambient temperature and pressure, molecules containing up to four carbon atoms can exist in the gaseous state; molecules having between five and fifteen carbon atoms are found in the liquid state, while the heavier molecules with more than eighteen carbon atoms occur as solids [1] [14].

The hydrocarbons are classified into three types, viz., aliphatic, cycloaliphatic and aromatic [15] [16]. Table 1 lists some examples of hydrocarbons and their characteristics [17] [18]. As shown, the molecular structure of the hydrocarbons may range from single-strand chains to the more complex forms, revealing branched chains or cyclic structures [3]. In terms of toxicity the aromatic hydrocarbons rank first, followed by the cycloaliphatic olefins and then the aliphatic ones.

The oil composition, according to Zílio and Pinto (2002) [19], can be defined by content, as given below:

- Saturated hydrocarbons include straight chains and branched alkanes (paraffin compounds) and cycloalkanes (naphthenic compounds);

- Aromatic hydrocarbons are composed of pure aromatic molecules, aromatic cycloalkane (naphthene-aromatic compounds) and occasionally, cyclic sulfur compounds;

Table 1. Characteristics and examples of the major hydrocarbon classes.

\begin{tabular}{|c|c|c|}
\hline Hydrocarbons & Characteristics & Examples \\
\hline Aliphatic & $\begin{array}{l}\text { - } \quad \text { Less dense than water; } \\
\text { - Molecule size is inversely proportional to its volatility and water solubility. }\end{array}$ & $\begin{array}{l}\text { Methane, propane, butane } \\
\text { (gas at room temperature); } \\
\text { hexane, octane, hexadecane } \\
\text { (liquidat room temperature); } \\
\text { Eicosane, Triacontane } \\
\text { and Pentacontane } \\
\text { (solid at room temperature). }\end{array}$ \\
\hline Cycloaliphatic & $\begin{array}{l}\text { - } \quad \text { Contain up to } 6 \text { carbon atoms in a ring; } \\
\text { - Fairly resistant to microbial degradation. }\end{array}$ & $\begin{array}{l}\text { Cyclohexane, methyl cyclohexane, } \\
\text { methylcyclopentane, } \\
\text { 1,2-dimethylcyclopentane. }\end{array}$ \\
\hline Aromatic & $\begin{array}{l}\text { - Very volatile and relatively water-soluble; } \\
\text { - Havebenzenering; } \\
\text { - Some are resistant to microbial degradation. }\end{array}$ & $\begin{array}{l}\text { Benzene, naphthalene, } \\
\text { toluene, xylene and phenanthrene. }\end{array}$ \\
\hline
\end{tabular}

(Adapted from Morrison, 1985) [17]. 
- Resins and asphaltenes, which cover the polycyclic compounds, include nitrogen, sulfur and oxygen and have high molecular weight.

Crude oil dissolves in most petroleum solvents; however, this property can vary with the type and quantity of the hydrocarbons occurring as impurities [3].

The American Petroleum Institute has classified crude oil and its derivatives based on their densities, on a hydrometric scale and expressed as API gravity.

On this scale, the oils are categorized as follows:

- Light Oil: API shows a higher degree of $31.1^{\circ}$ (density less than $870 \mathrm{~kg} / \mathrm{m}^{3}$ );

- Medium Oil: It shows API gravity between $22.3^{\circ}$ and $31.1^{\circ}$ (density ranging between 870 and $920 \mathrm{~kg} / \mathrm{m}^{3}$ );

- Heavy Oil: It reveals API gravity between $10.0^{\circ}$ and $22.3^{\circ}$ (density ranging between 920 and $1.000 \mathrm{~kg} / \mathrm{m}^{3}$ );

- Ultra Heavy Oil: It shows API gravity below $10.0^{\circ}$ (density greater than $1.000 \mathrm{~kg} / \mathrm{m}^{3}$ ).

\subsection{Contamination of Marine Environment by Crude Oil}

For example, as the Brazilian operation takes place principally in deep water, the chances of oil spills occurring on small and large scales increase in the production regions, as well as in the transport sea routes [11] [20]. Incidents involving spillage during shipping, as oil or even from the urban runoff platforms are common occurrences. Such incidents are, however, perceived as occasional spills and they inhibit the local biota, as well as the vicinity of the regions thus affected [21].

The new offshore oil fields discovered off the Brazil coastline, endanger a greater number of coastal ecosystems, which could face possible impacts due to oil spills [11]. Several islands and oceanic islands that support endemic plant and animal species and probably microorganisms too, as well as offer assistance points for many migratory birds, mammals and sea turtles [22] can be under threat. Therefore, oil spills of any intensity can result in grave environmental repercussions.

When oil spreads on the water surface during an oil spill, it forms a few millimeter-thick layer [23], causing a sharp decrease in the marine life in the affected area, during the initial days [24].

Volatile and low in molecular weight, these substances include the most toxic of the petroleum components [11] [25]. Factors like light, temperature, sea movements and local flora, besides others, directly influence the evaporation capacity of these light and volatile fractions. By photolysis, the sun's ultraviolet radiation oxidizes some of the hydrocarbons in the oil, producing acids and phenolic compounds, which may be more toxic than the hydrocarbons initially acted upon [22] [26] [27].

Some water soluble hydrocarbons dissolve in the sea, in particular, those with low molecular weight [11] [28] [29]. Despite being the most toxic components, only about $1 \%$ of these spilled oil constituents undergoes solubilization. Also, these compounds are easily degraded by microorganisms [22].

The heavier oil fractions descend to the ocean floor, especially after adsorption by the particulate matter available in the water column. This process typically takes place in small quantities and, in some instances, the oil may be rapidly metabolized by the benthic organisms [22], while in others it can remain for long time periods in the ocean sediment [24].

Under certain oceanic conditions, the oil and sea water may form an emulsion. However, this occurs only when water droplets, less than $0.1 \mathrm{~mm}$ in diameter, get mixed with the floating oil [22]. This emulsion, a viscous substance called 'mousse', may contain $20 \%$ to $90 \%$ sea water [30]-[32].

The mousse training and stability are dependent on the type of spilled oil [31]. The mousse can be formed even under calm sea conditions; however, during moderate sea conditions, more rapid mousse formation occurs, rendering it more stable, viscous and with a higher percentage of water. The spill persistence, as well as the mousse density and viscosity, increases proportionately in line with the sea water agitation and the percentage of high molecular weight oil constituents, like the asphaltenes and resins [31] [33]. Low ambient temperatures ensure a more stable emulsion [32]. Mousse density is also influenced by the salinity of the sea water. The greater the salt concentration, the denser the mousse and this increases the possibility of going down the water column and reaching the benthos region [30].

A spill occurring far from the shore permits a significant quantity of the hydrocarbons to evaporate and disperse in the ocean, affecting the coastal life to a lesser degree. Nevertheless, the sea conditions can facilitate mousse formation, which when it reaches the coast, damages the local biota. Due to its chronic toxicity, the mousse, which coats the plant and animal bodies, results in mass mortality in the environment thus affected [34]. 


\section{Biodegradability and Toxicity}

The microbial biodegradation of hydrocarbons occurring in the natural environments depends upon the physical, chemical and biological means. The degradation rates vary based on the composition, oil density and hydrocarbon concentration, as well as the dispersion and emulsification. Among the most important variable factors are temperature, oxygen concentration and nutrients. Salinity and pressure also affect the biodegradation rates in the aquatic environments. Algae, archaea, bacteria and fungi, primarily degrade the hydrocarbons utilizing them as carbon and energy sources [35]-[38].

The complex chemical structure of the hydrocarbons is inversely related to their capacity for biodegradation by the microorganisms. Low molecular weight aromatic hydrocarbon components like benzene, toluene and xylene impose immediate toxic effects on the affected environment, but are easily degraded by the environmental microorganisms [37]-[40]. While the molecules with two or more fused aromatic rings or branches pose greater difficulty for degradation, with correspondingly fewer number of microorganisms endowed with such capability, compared with the simpler molecules, the yareless toxic. However, they are more persistent in the environment and leave longer lasting effects, termed 'chronic toxic effects' [34] [41].

\subsection{Biodegradation}

Hydrocarbons degrading microorganisms are distributed widely across the marine ecosystems, limnological environments and soils [42]. This is one of the chief mechanisms by which oil and its derivatives are eliminated from contaminated environments [43]. Several biotic and abiotic factors, involved in hydrocarbon degradation, continue to spur the scientific community's interest in research [36] [42] [44]-[47].

As the hydrocarbons possess different conformations and molecular weight, they have distinct susceptibilities to biodegradation; biodegradation of the hydrocarbon present in the oil normally drops, depending upon the complexity of the molecules. Microorganisms find the n-alkanes the easiest to degrade, followed by the branched chain alkanes, branched alkanes, n-alkyl branched low molecular weight, monoaromatic, cyclic alkanes, polycyclic aromatic hydrocarbons (PAHs), and finally, the asphaltenes, which are the most difficult [27]. Biodegradation involves hydrocarbon catabolism, to produce less complex molecules which, after complete digestion, are converted into water and carbon dioxide under aerobic conditions, or to methane in anaerobic conditions [37].

The formation of emulsions to produce and release biosurfactants by the microbial populations plays a vital role in the oil uptake by bacteria and fungi [48]-[50]. Although protozoa and algae are important members of the microbial community in aquatic environments, little is known about their role in hydrocarbon biodegradation [51].

Biodegradation of the naturally occurring petroleum hydrocarbons in the environments is influenced by the indigenous microorganisms which can physiologically degrade them. Various abiotic factors also influence the growth and activity of these microorganisms [36] [37] [41]. The persistence depends on the do pant quantitatively and qualitatively, as the hydrocarbons can linger on indefinitely, while in others, due to the influence of different physical and chemical factors, they can be rapidly degraded by the local microbiota [38] [43].

Temperature affects oil degradation as it interferes with the aspects of oil viscosity and solubility, including fluidity. It also influences the metabolism of the microorganisms and the composition of the microbial communities. At low temperatures, the oil viscosity increases, and the volatilization of the toxic components and microbial activity decrease [52] [53]. However, biodegradation of the hydrocarbons at low temperatures has been reported [54], between $0^{\circ} \mathrm{C}[55]$ and $60^{\circ} \mathrm{C}[56]$ [57].

Another limiting factor is oxygen, as it promotes the oxygenase enzymes to oxidize the aliphatic, cyclic and aromatic hydrocarbons. In the water column of the marine environments, oxygen is not normally a limiting factor, particularly in the coastal areas [43] [58]. Due to the complexity of the substrates present in the oil, the co-oxidation of the hydrocarbons by the microorganisms can still occur. In many environments contaminated with oil the branched and cyclic hydrocarbons are removed via co-oxidation [58]-[60].

When an environment becomes contaminated with hydrocarbons, the carbon and nitrogen as well as carbon and phosphorus ratios are very large. This is contraindicative to microbial growth [61]. In such situations, the nitrogen and phosphorus become the limiting factors for biodegradation and an adjustment in the ratios of carbon and nitrogen and phosphorus becomes necessary, by the addition of nitrogenous compounds and inorganic phosphate to facilitate microbial growth and, consequently, the hydrocarbons become the carbon source [62] [63]. 
For biodegradation in deep water, pressure appears to play a significant role. Colwell and Walker (1977) [43] purported that the oil which reaches the sea bed is subjected to high pressures and microbial degradation occurs very slowly. This results in the recalcitrant oil fractions remaining in the environment for several years.

Various microbial genera have been described for their ability to degrade the petroleum hydrocarbons. Of these, some like Pseudomonas, Vibrio, Acinetobacter, Flavobacterium, Rhodococcus, Achromobacter and Corynebacteria are well known for their ability to use the hydrocarbons in water [37] [42] [64]-[67]. Some microorganisms utilize only the aromatic compounds, while others use only the alkanes; however, there are some which can use both types of hydrocarbons [39] [42] [43].

In marine environments with no reported oil contamination by humans, hydrocarbon-consuming microorganisms form less than $0.1 \%$ of the total microbial community; however, in oil-polluted environments, they can represent up to $100 \%$ of the viable microorganisms [39]. To adapt to the new environmental conditions, the microbial community undergoes physiological and genetic changes, involving mainly the horizontal transfer of genes contained in the mobile genetic elements concerned with the metabolism of the contaminants [68].

\subsection{Toxic Effects of Petroleum Hydrocarbons}

The marine environment, among the world's biomes, receives the most waste and contaminants as products of human activity. Estuaries, which form one of the most biologically productive habitats on the earth, are often threatened by human activities, oil spills and its derivatives being significant contributors [69].

The scientific community and society recognize the difficulties and immediate effects that result from direct contact with oil spills in the environment. They can be easily observed in the form of a scale on the rocks, sand, animals and plants, besides as the imbalance caused in the microbial communities [34] [37] [70]. Apart from these immediate effects, chronic and sublethal effects are experienced by the biota medium for prolonged time periods which are harder to identify [34] [41] [69] [71].

The prevalence of acute or chronic toxicity in the environment depends chiefly upon the type of oil spilled. High density oil leaves a predominant effect of physical coating, whereas the low density oil reveals the chemical effect as the prominent one. As the most toxic compounds are more soluble and volatile, chemical toxicity is felt during the very first days and weeks after the oil spill. The abiotic and biodegradation performed by the microorganisms enables the removal of these components from the environment [72]. Alkanes, also termed paraffins, represent the majority of the crude oil and can induce anesthetic and narcotic effects. The bodies of the marine organisms in contact with toxic oil fractions, of low and high molecular weights, may result in death by poisoning; this phenomenon is associated with the aromatics, in particular [2] [73].

Of the hydrocarbons that exert chronic toxic effects on biota, the Polycyclic Aromatic Hydrocarbons (PAHs) are the most widespread contaminants in the environment. Their toxic effects have been the subject of several studies [73]-[77].

While the alkanes are easily degraded by the microorganisms, those with five to ten carbon atoms can inhibit the degradation process as they can destroy the bacterial cytoplasmic membrane [78]. The low molecular weight hydrocarbons have an acute toxic effect, because of their high solubility in water and consequent bioavailability [72].

Once they enter the marine environment, chiefly in the coastal areas, the PAHs quickly get associated with suspended particulate matter, due to their low water solubility and high hydrophobicity [77] [79]. They are consequently deposited in the sediment. The pellet thus becomes a reservoir containing the contaminants in the marine biota exerting their ecotoxicological effects for long periods of time. The low solubility in water, the volatilization and difficulty in increasing the persistence of the recalcitrant properties, as well as the likelihood of these compounds getting accumulated in the environment [77] [80]. Some PAHs can damage the DNA, thus inducing mutations and exerting carcinogenic effects [73] [76]. Some studies reported that the PAHs are the main mutagenic agents formed from the sediment cores [74]. A positive relationship between mutagenesis and contamination with PAH has been established [75].

Apart from genetic damage, oil spills can affect organisms by the inhibition of the growth rates and reproductive success, increased sensitivity to pathogens and irreversible impairment of the immune system [69] [81].

\subsection{Impacts of the Hydrocarbons on the Biota}

To assess the impacts induced by environmental disasters due to oil spill, as well as the risks to the current and 
future generations of the members of the local biota, the evaluation of several factors is mandatory, along with the application of different models with several environmental variables, as well as monitoring some of them [71]. The literature includes some research related to the impacts of oil on the natural environments [11] [82][85].

The unforgettable accident of the Exxon Valdez on March 24, 1989, in Alaska, was of such immense magnitude that it has since then been the subject of research [84]. In that spill, 42 million liters of crude oil poured into the ocean, contaminating $1.990 \mathrm{~km}$ of coastline, impairing the "Prince William" cove the most. Negatively affecting the algal growth, due to the high toxicity of the hydrocarbons, the consequent result was a huge imbalance throughout the entire food chain. The abundance of fish fauna, crabs, starfish, sea and invertebrates dropped alarmingly, as did the amphipods sensitive to the toxic oil components. However, some invertebrate communities, especially the oligochaetes and polychaetes revealed a spurt in abundance, which probably was not only due to the increased number of hydrocarbon degrading bacteria, but also to the decrease in their predators [83]. Further studies, Carls et al. (2001) [82] found that six years after the disaster there continued to be persistent plumes and oil-contaminated sediment, which in turn became a source of contamination for the local species.

Birds, turtles and marine mammals frequently require contact with the water surface to breathe. When, the oil covering the water surface prevents these animals from surfacing, there is a rapid decline in their population [84]. Lubricating feathers and animal hair, the oil causes them to lose their insulation powers, inducing death from hypothermia, suffocation, drowning and sometimes mortality by contact and ingestion of the toxic hydrocarbons [85]. The oil adhering to the body surface causes thermal stress to the sea otters and polar bears, resulting in decreased body temperature and increased metabolic rate [86].

\section{Remedial Environmental Strategies for Oil Removal in Marine Environments}

To clean up oil spills and their derivatives the remediation alternatives available include the physical, chemical and biological treatments. These treatments often cause the pollutant dispersion as part of its effective removal, limiting its effectiveness, besides running up high costs. However, removal through remediation using microorganisms, involves low cost, high efficiency and eliminates secondary pollution, when compared with other methods [63] [87]. Therefore, this method offers a competitive alternative in mitigating the impacts caused by the petroleum hydrocarbon contamination. Of the prevalent remediation technologies, none provide such a high efficiency of contaminant removal. However, the effectiveness of pollutant removal from contaminated environments can be enhanced when the remediation methods are used together [88] [89].

When introduced into the marine environments, the oil and its derivatives undergo a several changes due to the physical, chemical and biological conditions, including evaporation, dissolution, dispersion, photo-oxidation, emulsification, adsorption onto particulate and sedimentary materials, and biodegradation [41] [90]. As these processes take place simultaneously, they cause some changes in the physical and chemical properties of the pollutant, which in turn directly affect the hydrocarbons during the time they remain in the environment [37].

\subsection{Physics and Chemistry Remediation}

In order to help recover and disperse/solubilize the oil spilled in marine environments different types of physical and chemical remediation techniques are employed in which equipment or chemicals are introduced into the contaminated sites. From a biological point of view, the chemicals used in the treatment may themselves be highly toxic, posing of an ecological risk [91]. When in contact with the aquatic organisms, these compounds can interfere in embryogenesis, larval growth and survival and result in morphological changes in the local biota. During the early stages of life, a body is more sensitive to disturbances compared with the adult stages; therefore, species with a fast lifecycle are more likely to suffer from the toxic effects [92] [93].

Beiras et al. (1999) [93] demonstrated that a higher concentration of total petroleum hydrocarbons (TPH) is dispersed in the water column when are used dispersants at sea. As an alternative to dispersion of the burned oil on the sea surface, Gundersen et al. (1996) [94] demonstrated that the water soluble fraction of partially burnt oil is ten times less than that of crude oil; however, the soluble fraction that gets retained in the water column has greater potential for acute toxicity to some of the biota. However, burning the oil has been demonstrated to have less or no toxic effect on the water, increasing the probability that marine organisms in contact with the 
dopant, either by airways, diffusion through the skin and power, increases the problem of bioaccumulation in living tissue [70] [95].

To restrict the oil spill, containment booms can be used to block and redirect the slick to places where the clean-up operation is easier, as well as to prevent the pollution from reaching areas of ecological/socio-economic interest. Equipment like skimmers and absorbent granules are used in this technique [96] [97]. Oil gathering is dependent on the weather, tide and the physicochemical properties of the oil. Although it does not disturb the environment, the collection of oil using such barriers is quite inefficient because the environment fractions are dissolved in the water, as well as those adsorbed on particulate material go down to the benthic environment [37] [80] [98]. Washing the oil stuck on rocks and sand in the coastal regions is another commonly used alternative. In light of the situation, various strategies are performed by utilizing cold or hot water, and low or high pressure [99].

Sometimes, chemical agents termed "demulsifiers" are used to reduce the oil dispersed in water, to prevent the formation of emulsions of oil in water. Gelling agents may be used to increase the polymerization of the oil to stabilize and minimize the stain from spreading. This will facilitate easy and effective physical removal operations. Further, certain chemicals can be applied to the substrates in coastal areas, to prevent the oil from adhering to the rocks and sediments, thus enabling a more effective clean-up than the procedure of washing with high pressure [99].

Aircraft or ships can be used to spray chemical dispersants on the slick, to accelerate the oil dispersion, as well as ease the solubility and enhance the degradation by microorganisms. The surfactants act like a detergent. They have a lipophilic portion and a hydrophilic one, which enables affinity both with water and with oil. Thus, when applied to a thin oil layer, the surfactant diffuses in the water/oil interface; the lipophilic fraction binds to the oil, while the hydrophilic molecule binds to the water, thus reducing the interfacial tension between the two phases [100]. This results in the formation of micelles of the surfactant with the aggregated oil particles, making the oil soluble and more accessible to the microorganisms for degradation. However, evaluation of the oil type, climatic conditions as well as size and location of the site must be done, because when high density oil is to be cleaned up, the efficiency is low; also, sea agitation on the surfactant promotes micelle formation [97].

Although surfactants have proved useful in oil solubility to minimize the impacts caused by the oil spill in marine and coastal environment, there is a pressing need for the removal of the contaminants remaining in the water. This is because the amounts of pollutants remaining in the environment can result in an ecological "silent" disaster, chronically intoxicating the biota of the contaminated ecosystem [34] [70].

\subsection{Bioremediation}

Utilization of microorganisms for decontamination of the environments in several ecosystems appears promising and effective. Although the microorganisms capable of degrading oil are ubiquitous, they usually occur in small proportions in the microbial communities. Hundreds of species, including bacteria, archaea and fungi have the ability to degrade the hydrocarbons present in oil [39] [42] [67] [101].

The bioremediation of contaminated sites is dependent upon the metabolic pathways in the microorganisms to convert the pollutant organic compounds are nontoxic or at least less harmful to the environment [102] [103].

Several petroleum hydrocarbons can be biodegraded aerobically, whereas some compounds likes resins, polar molecules and asphaltene can hardly be catabolized by them. Light-density oils contain a large percentage of hydrocarbons of simple molecules with low molecular weight, and they are more easily metabolized by the degrading microorganisms; higher density oils with larger hydrocarbon molecules and higher molecular weight are recalcitrant. The PAHs usually occur in low concentrations in crude oil; however, they are highly toxic and difficult to remove from the contaminated sites [101]. Bacteria can convert the PAHs completely into carbon dioxide and water in the presence of oxygen, by the action of enzyme dioxygenase [38]. Some microorganisms can also degrade hydrocarbons under anaerobic conditions, although it is less energetically advantageous when compared to those done under the aerobic conditions [101] [104].

The bioremediation techniques may be classified as ex situ and in situ. In the ex situ type, the contaminant is removed from the environment and treated elsewhere. The in situ technology appears to have several advantages because it does not require the removal and transportation of the contaminated material. Remediation processes in situ utilized in the field are differentiated into natural attenuation, bioaugmentation and biostimulation [105]. Table 2 lists some results from studies that have utilized the bioremediation strategies in situ. 
Table 2. Studies on the bioremediation strategies in marine environments.

\begin{tabular}{|c|c|c|c|}
\hline Strategy & Characteristics & Results & Reference \\
\hline $\begin{array}{l}\text { Natural attenuation } \\
\text { Bioaugmentation }\end{array}$ & $\begin{array}{l}\text { Mangrove sediment }(4 \mathrm{~g}) \\
\text { contaminated with fluorene, } \\
\text { phenanthrene and pyrene } \\
\text { (400 mg cada) in } 40 \mathrm{~mL} \\
\text { of artificial seawater. }\end{array}$ & $\begin{array}{c}97 \% \text { removal of fluorene and } 99 \% \\
\text { of phenanthrene after } 14 \text { days. } \\
97 \% \text { removal after } 14 \text { days } \\
\text { of fluorene and } 97 \% \text { removal } \\
\text { after } 28 \text { days of phenanthrene. }\end{array}$ & [104] \\
\hline Biostimulation & $\begin{array}{l}\text { Mangrove sediment }(4 \mathrm{~g}) \\
\text { contaminated with fluorene, } \\
\text { phenanthrene and pyrene } \\
\text { (400 mg each) in } 40 \mathrm{~mL} \text { of } \\
\text { Mineral Salt Medium (MSM). }\end{array}$ & $\begin{array}{c}97 \% \text { removal of fluorene, } \\
\text { phenanthrene and pyrene } \\
\text { after } 28 \text { days. }\end{array}$ & \\
\hline Biostimulation & $\begin{array}{l}\text { Seawater contaminated with } \\
\text { diesel }+\mathrm{NaNO}_{3}+\mathrm{KH}_{2} \mathrm{PO}_{4} \\
\text { (ratio } \mathrm{N}: \mathrm{P} \text { equal to } 10: 1 \text { ) }\end{array}$ & $\begin{array}{c}24.6 \% \text { removal of } \\
\text { diesel after } 32 \text { days. }\end{array}$ & {$[106]$} \\
\hline Biostimulation & $\begin{array}{c}\text { Seawater contaminated with light } \\
\text { crude oil }(1 \mathrm{~g} / \mathrm{L}) \text {, using } \mathrm{KNO}_{3}+\mathrm{K}_{2} \mathrm{HPO}_{4} \\
\text { (ratio } \mathrm{N} \text { : P equal to } 10: 1)+ \\
\text { chemical surfactant }\end{array}$ & $\begin{array}{l}53.4 \% \text { removal of total } \\
\text { petroleum hydrocarbons } \\
\text { after } 28 \text { days. }\end{array}$ & [107] \\
\hline Biaugmentation + biostimulation & $\begin{array}{l}\text { Seawater contaminated with crude } \\
\text { oil }(1 \mathrm{~g} / \mathrm{L})+\text { chemical surfactant }+ \\
\mathrm{NH}_{4} \mathrm{NO}_{3}+\mathrm{K}_{2} \mathrm{HPO}_{4} \\
\text { (ratio } \mathrm{N}: \mathrm{P} \text { equal to } 10: 1)\end{array}$ & $85.35 \%$ removal of $n$-alkanes. & \\
\hline Bioaugmentation + biostimulation & $\begin{array}{l}\text { Seawater contaminated with } \\
\text { crude oil }(0.5 \% \mathrm{w} / \mathrm{v}) ; \mathrm{KNO}_{3}+\mathrm{K}_{2} \mathrm{HPO}_{4} \\
\text { (ratio C: } \mathrm{N}: \mathrm{P} \text { equal to } 100: 10: 1) \\
\text { + rhamnolipid + pre-culture } \\
\text { adapted microorganisms }\end{array}$ & $\begin{array}{l}99 \% \text { removal of } n \text {-alkanes } \\
\left(\mathrm{C}_{14}-\mathrm{C}_{35}\right) \text { in } 15 \text { days. }\end{array}$ & {$[108]$} \\
\hline
\end{tabular}

\subsubsection{Natural Attenuation}

The natural attenuation method involves decreasing the concentration of the contaminants from the environment by the natural degradation processes. This technology requires modeling the evolution of pollutant disposal. Therefore, characterization of the areas affected, sampling at specific locations and chemical analysis need to be checked for contaminant degradation in the natural environment over time [105]. Under certain conditions, natural attenuation was normally employed in the coastal areas, or even to monitor groundwater, because technologically and economically, such bioremediation appears to be a feasible method. Invasive cleaning methods are not preferred as they can prove harmful to the local biota [109] [110].

Oil concentrations in the coastal areas decrease by natural attenuation, through evaporation governed by factors like temperature and wave movement. The dissolved oxygen present in abundance no longer acts as a limiting factor for microbial growth, although phosphorus and nitrogen in low concentrations behave as limiting factors in the process [42] [111] [112].

In the water column or on the benthic region, microorganism-mediated degradation is slower because the electron acceptors, the oxygen in particular, are not available in sufficiently large quantities for the oxidation of the hydrocarbons. Also, some nutrient deficiency due to the lack of minerals and low temperatures could be a reason. Some bacteria can accomplish the hydrocarbon biodegradation limiting their activity to spots near the center of the oil patch, where the degradation occurs at a slower pace [113] [114].

In 2002, an accident which resulted in a heavy oil spill a few hundred miles off the Spanish coast, from where it reached right up to the coast, was studied by Gallego et al. (2006) [115]. One year after the accident, without any intervention to the environment, it was discovered that about $100 \%$ of the linear low-molecular weight alkanes and $35 \%$ of the aromatic hydrocarbons, like pyrene, were no longer reported in the environment. Via microscopy imaging, metabolically active microbial consortia were observed to degrade the hydrocarbons. After the oil spill the subsequent emulsification and evaporation processes besides other photochemical oxidation processes are very effective in the removal of the oil fractions [99]. 


\subsubsection{Bioaugmentation}

Bioaugmentation is a bioremediation strategy. To apply this method, one must begin with the premise that the indigenous microbial community has a metabolic capacity insufficient to catabolize the pollutants, and that, to increase the genetic diversity in the middle, the cleaning process needs to be optimized, for higher efficiency of the biodegradation process. Bioaugmentation is defined as the strategy for improving the ability of a contaminated environment to eliminate or mitigate the effects of the pollution by the introducing specific strains or microbial consortia capable of catabolizing the polluting compounds [42] [43] [102] [116].

McKew et al. (2007) [116] reported that bioaugmentation, tested in microcosm, was a good strategy to accelerate the degradation of components like n-alkanes, branched alkanes and PAHs during the first five days after contamination. Baoetal (2012) [87] also noted that, while applying a microbial consortium to degrade the crude oil, the highest rate of oil biodegradation occurred in the early phases just after contamination.

The success of any bioremediation strategy, including bioaugmentation, is dependent upon the environmental conditions of the contaminated site. As bioaugmentation necessitates the quick adaptation of the microorganisms introduced into the environment, this factor becomes relevant. The methods implemented when applying the bioaugmentation strategy are as follows: addition of pre-adapted inbred lines, pre-addition of suitable microbial consortia, introduction of genetically modified bacteria having a gene set relevant to the biodegradation required and which in combination may be transmitted to the autochthonous microorganisms [102].

From an applied perspective, utilization of a microbial consortium is more advantageous than the use of a pure culture, due to its greater metabolic diversity and increased ability to adapt to the field conditions [117][119]. Thus, the use of microbial consortia is a good alternative to clean up the oil-contaminated sites, and even when the sites are co-infected by another pollutant. Specifically, in the case of crude oil-contaminated sites, due to the diversity of hydrocarbons present, the application of a consortium of microorganisms can optimize the process. This is because the degradation product of one microorganism can become the foundation of another. Further, in particular, when co-contamination occurs, the metabolic activity of some microorganisms can become inhibited by any one environmental contaminant. Thus, when a consortium is used, other microorganisms that have adapted to those conditions can degrade it and facilitate the establishment of other populations before they are inhibited, thus ensuring the success of the bioremediation process [120].

From the ecological angle, some barriers to the success of bioaugmentation have been identified. Factors, like the relationship between the microorganisms inoculated with new biotic and abiotic factors, will interfere with the survival and metabolic activity of the inoculum. Among the biotic factors, predation by protozoa and competition with native organisms for nutrients and electron acceptors are the negative elements for the success of bioaugmentation [121] [122]. In the marine environments, the main factors include the adaptation to salinity, oxygen concentration and water movement. The stress conditions that the microorganisms face that occur after their transfer from the culture medium to the contaminated environment typically result in a decrease in the populations of the inoculated microorganisms. Variable factors like temperature fluctuations, $\mathrm{pH}$, nutrient concentrations and contaminant toxicity may account for the low process efficiency [42] [123]. Goldstein et al. (1985) [124] showed that microorganisms capable of degrading organic pollutants failed when the cultures were introduced into the natural environments. Although still unsure of the reasons, the possibility for the failure to adapt could be substrate failure, competition with indigenous microorganisms, preference for another organic substrate and protozoan predation.

Another technique can be employed when the microbial community of the contaminated environment begins to degrade the pollutant; however, it is not feasible to wait until those microorganisms achieve high densities. In such instances, bioaugmentation can be employed using pure cultures or microbial consortia of the indigenous microorganisms, which have proven to be effective in the bioremediation processes, particularly in accidents involving oil spills in the marine environment [108]. Apparently, the indigenous microorganisms selected prior are more likely survive and spread in the environment after release, when compared with those microorganisms isolated from other sites [125] [126].

Despite some disadvantages, bioaugmentation indicates that it can be an efficient method for the removal of environmental pollutants. The suitability of the processes involved, as well as the continuous search for microorganisms that can find use as degraders in contaminated environments, indicate that bioaugmentation may emerge as one of the few environmentally friendly techniques to clean up contaminated sites [63] [102] [108].

\subsubsection{Biostimulation}

In the aquatic environments bioremediation is limited by the availability of nitrogen and phosphorus, the two 
components essential for microbial growth [126]. In cases involving oil spills, there is a high probability that bacteria in the contaminated water are capable of metabolizing the hydrocarbons [42] [67] [125] [127]. Despite the presence of microorganisms with such capacities in the contaminated water, their growth will be limited by the high ratios of C:N and C:P [20] [128]. The addition of nitrogen and phosphorus as fertilizers is, therefore, considered an effective method of stimulating microbial growth and activity, and thereby enabling catabolism of the oil [101]. This technique of adding nutrients, as well as electron acceptors and other compounds to maintain the conditions that will stimulate microbial growth, is termed biostimulation.

Besides the addition of compounds for microbial metabolism, modifications in the environmental conditions can also optimize the rate of oil biodegradation, for example, the when compounds to modify the $\mathrm{pH}$ of the medium are added to stimulate microbial metabolism [39]. Compared with terrestrial environments, biostimulation processes in marine environments should be used with great caution and further study is warranted [63]. The most important factor is that when the bio-stimulants are added they should come into contact with the microorganisms near the oil spill; also, they should not have high solubility in water, as they may get dispersed in the ocean and achievement of the desired effect will be unsuccessful. When applied to sites where the dispersion is slower, care must be taken to avoid eutrophication of the environment so that the accelerated algal growth may reduce the concentration of oxygen dissolved in the water [129]. Temperature is a critical factor in the degradation processes, but unfortunately it cannot be controlled in situ applications. Temperature variations exert different effects on the petroleum biodegradation process; first, the oil viscosity is affected, its own solubility in water, chemical composition, and its influence on the metabolic rates of the microbial community [34] [39] [42].

From the accident involving the Deepwater Horizon spill in 2010 an estimated 780 million liters of oil was released into the Gulf of Mexico, affecting an area of 75,000 km². After seven months of cleaning-up activities it was revealed that approximately $41 \%$ of the evaporated oil was dissolved or dispersed in the water by natural conditions, while $33 \%$ was chemically removed, dispersed via surfactant action, burnt or removed by remediation processes; however, the remaining $26 \%$ posed a potential threat to the local biota [130]. In such cases, the fertilizer was applied only in swampy regions where dispersion did not pose a problem [131]. In areas quite far from the Gulf of Mexico coast, because of the oligotrophic nature of the water, bacterial activity studies in the oil stain area showed an increased rate of microbial respiration after the addition of the inorganic nutrients. Phosphate was identified as a limiting nutrient in the oil biodegradation rate. Laboratory studies have shown that the use of fertilized clay mineral flakes, the principle being that nutrients are limiting in offshore water, and could be used to increase the biodegradation and thus restricting the oil from spreading [132].

One of the detriments for the implementation of biostimulation in ocean waters is the high solubility of the compounds which reduce its effectiveness when added outdoors. Atlas and Bartha [61] worked on the effectiveness of various nitrogenous compounds having different oleophilic the $\mathrm{C}: \mathrm{N}$ ratios. After the oil spill during the Exxon Valdez accident, one oleophilic fertilizer (EAP Inipol 22) was used in the coastal regions [36] [133], but some reported [134] [135] that the effectiveness of the process was not proven [136].

Uric acid, a compound rich in nitrogen but with low solubility in water was used in the experiments of Koren et al. (2003) [137] as a nitrogen fertilizer. The results indicated that it was a nitrogen source for the bacteria that degrade the hydrocarbons. As it binds to the crude oil, it proves to be a potentially useful fertilizer and can be applied in the oil bioremediation process in open systems, because its molecules can remain adsorbed on the oil.

\section{Conclusions}

The use of remediation strategies in oil spills has been the object of significant investment in terms of research and development for recent decades. Despite the contribution of several researchers emanating from the field of application, no definitive application has evolved into an everyday real-life one.

Despite the bioremediation processes are a great alternative, the effectiveness of pollutant removal from contaminated environments can be enhanced when the remediation methods are used together [88]. The use of $\mathrm{N}$ and $\mathrm{P}$ sources of the compounds used with the biosurfactants enables the naturally occurring microorganisms present in the environment to better identify and more rapidly degrade the contaminant.

Other possible combinations include the employment of bioaugmentation, biostimulation and the addition of biosurfactants, depending on the contaminant's biotic and abiotic characteristics [138]. The development of autochthonous microorganisms post the addition of the biostimulants in a contaminated environment is a slow process [108]. Therefore, considering the limitations of the individual application of both bioaugmentation and 
biostimulation, it is interesting to note that the complementarity among them makes the decontamination process more effective. Due to the complexity of each method of standardization, a single bioremediation method is not possible. Therefore, microorganisms of interest are selected for each site, which is possibly the best option [86].

\section{Acknowledgements}

This work was supported by Conselho Nacional de Desenvolvimento Científico e Tecnológico (CNPq), Coordenação de Aperfeiçoamento de Pessoal de Nível Superior (CAPES) and Fundação de Amparo à Pesquisa do Estado de Minas Gerais (FAPEMIG).

\section{References}

[1] Brown, D.W., Ramos, S.L., Friedman, A.J. and MacLeod, W.D.J. (1979) Analysis of Trace Levels of Petroleum Hydrocarbons in Marine Sediments Using a Solvent/Slurry Extration Procedure. In: Hertz, H.S. and Chesler, S.N., Eds., Trace Organic Analysis: A New Frontier in Analytical Chemistry, 9th Edition, U.S. Government Printing Office, Washington DC, 161-167.

[2] Speight, J.G. (2007) The Chemistry and Technology of Petroleum. 4th Edition, CRC Press, New York.

[3] Halliburton, A.D. (2001) Basic Petroleum Geology and Log Analysis. Halliburton Company.

[4] Bentley, R.W. (2002) Global Oil \& Gas Depletion: An Overview. Energy Policy, 30, 189-205. http://dx.doi.org/10.1016/S0301-4215(01)00144-6

[5] Aguilera, R.F., Eggert, R.G., Lagos, C.C.G. and Tilton J.E. (2009) Depletion and the Future Availability of Petroleum Resources. Energy Journal, 30, 141-174.

[6] Stone, R.W. and ZoBell, C.E. (1952) Bacterial Aspects of the Origin of Petroleum. Journal of Industrial and Engineering Chemistry, 44, 2564-2567. http://dx.doi.org/10.1021/ie50515a030

[7] Welte, D.H. and Yokler, A. (1980) Evolution of Sedimentar Basins from the Standpoint of Petroleum Origin and Accumulation-An Approach for a Quantitative Basin Study. Organic Geochemistry, 2, 1-8. http://dx.doi.org/10.1016/0146-6380(80)90016-9

[8] Kissin, Y. (1987) Catagenesis and Composition of Petroleum: Origin of n-Alkanes and Isoalkanes in Petroleum Crudes. Geochimica et Cosmochimica Acta, 51, 2445-2457. http://dx.doi.org/10.1016/0016-7037(87)90296-1

[9] Tissot, B.P. and Welte, D.H. (1984) Diagenesis, Catagenesis and Metagenesis of Organic Matter. In: Tissot, B.P. and Welte, D.H., Eds., Petroleum Formation and Occurrence, Springer-Verlag, New York, 69-73. http://dx.doi.org/10.1007/978-3-642-87813-8 6

[10] Martinelli, G. (2009) Petroleum Geochemistry Petroleum Engineering-Upstream. UNESCO-EOLSS, Reggio Emilia, Italy.

[11] ANP (2011) Anuário Estatístico Brasileiro do Petróleo, Gás Natural e Biocombustíveis. Agência Nacional do Petróleo, Gás Natural e Biocombustíveis.

[12] Altkins, P.W. (2001) Princípios de Química: Questionando a vida moderna e o meio ambiente. Artmed, Porto Alegre.

[13] Sharkey, T.D. (1996) Isoprene Synthesis by Plants and Animals. Endeavour, 20, 74-78. http://dx.doi.org/10.1016/0160-9327(96)10014-4

[14] McCain Jr., W.D. (1990) Components of Naturally Occurring Petroleum Fluids. In: McCain Jr., W.D., Ed., Properties of Petroleum Fluids, PennWell Books, Tulsa, 1-45.

[15] Evans, S.R. and Rice, S.D. (1974) Effects of Oil on Marine Ecosystems: A Review for Administrators and Policy Makers. Fishery Bulletin, 72, 625-638.

[16] Gerlach, S.A. (1981) Marine Pollution: Diagnosis and Therapy. Springer-Verlag, Berlin. http://dx.doi.org/10.1007/978-3-642-68182-0

[17] Morrison, R.T. (1985) Quimica Organica. 2nd Edition, Fondo Edicativo Interamericano, S.A. de C.V., San Marcos.

[18] Milanelli, J.C.C. (1994) Efeitos do petróleo e da limpeza por jateamento de um costão rochoso da Praia de Barequeçaba, São Sebastião, São Paulo. Universidade de São Paulo, São Paulo.

[19] Zílio, E.L. and Pinto, U.B. (2002) Identification and Distribution of the Main Groups of Components Present in Brazilian Crude Oils. Boletins Técnicos da Petrobras, 45, 21-25.

[20] ANP (2012) Indústria Nacional do Petróleo e do Gás Natural. Anuário Estatístico Brasileiro do Petróleo, Gás Natural e Biocombustíveis, Agência Nacional do Petróleo, Gás Natural e Biocombustíveis, 1-17.

[21] Petrobras (2012) Atuação no Pré-Sal. 
http://www.petrobras.com.br/pt/energia-e-tecnologia/fontes-de-energia/petroleo/presal/

[22] Kingston, P.F. (2002) Long-Term Environmental Impact of Oil Spills. Spill Science \& Technology Bulletin, 7, 53-61. http://dx.doi.org/10.1016/S1353-2561(02)00051-8

[23] Gundlach, E.R. and Hayes, M.O. (1978) Vulnerability of Coastal Environments to Oil Spill Impacts. Marine Technology Society Journal, 12, 18-27.

[24] Silva, E.M., Peso-Aguiar, M.C., Navarro, M.F.T., Barros, C. and Chastinet, A. (1997) Impact of Petroleum Pollution on Aquatic Coastal Ecosystems in Brazil. Applied and Environmental Microbiology, 16, 112-118. http://dx.doi.org/10.1002/etc.5620160112

[25] Fay, J.A. (1971) Physical Processes in the Spread of Oil on a Water Surface. International Oil Spill Conference Proceedings, 1971, 463-467. http://dx.doi.org/10.7901/2169-3358-1971-1-463

[26] Blumer, M., Sanders, H.L., Grassle, J.F. and Hampson, G.R. (1971) An Ocean of Oil: A Small Oil Spill. Environment: Science and Policy for Sustainable Development, 13, 37-41. http://dx.doi.org/10.1080/00139157.1971.9930568

[27] Haritash, A.K. and Kaushik, C.P. (2009) Biodegradation Aspects of Polycyclic Aromatic Hydrocarbons (PAHs): A Review. Journal of Hazardous Materials, 169, 1-15. http://dx.doi.org/10.1016/j.jhazmat.2009.03.137

[28] Eastcott, L., Shiu, W.Y. and Mackay, D. (1988) Environmentally Relevant Physical-Chemical Properties of Hydrocarbons: A Review of Data and Development of Simple Correlations. Oil and Chemical Pollution, 4, 191-216. http://dx.doi.org/10.1016/S0269-8579(88)80020-0

[29] Sabaté, J., Bayona, J.M. and Solanas, A.M. (2001) Photolysis of PAHs in Aqueous Phase by UV Irradiation. Chemosphere, 44, 119-124. http://dx.doi.org/10.1016/S0045-6535(00)00208-3

[30] Bridié, A.L., Wanders, T.H.H., Zegveld, W. and Van Der Heijde, H.B. (1980) Formation, Prevention and Breaking of Sea Water in Crude Oil Emulsions "Chocolate Mousses". Marine Pollution Bulletin, 11, 343-348. http://dx.doi.org/10.1016/0025-326X(80)90279-9

[31] Thingstad, T. and Pengerud, B. (1982) The Formation of "Chocolate Mousse" from Staffjord Crude Off and Seawater. Marine Pollution Bulletin, 14, 214-216. http://dx.doi.org/10.1016/0025-326X(83)90254-0

[32] Shiu, W.Y., Bobra, M., Bobra, A.M., Maijanen, A., Suntio, L. and Mackay, D. (1990) The Water Solubility of Crude Oils and Petroleum Products. Oil and Chemical Pollution, 7, 57-84. http://dx.doi.org/10.1016/S0269-8579(05)80034-6

[33] Fingas, M. and Fieldhouse, B. (2004) Formation of Water-in-Oil Emulsions and Application to Oil Spill Modelling. Journal of Hazardous Materials, 107, 37-50. http://dx.doi.org/10.1016/j.jhazmat.2003.11.008

[34] Aske, N., Kallevik, H. and Sjöblom, J. (2002) Water-in-Crude Oil Emulsion Stability Studied by Critical Electric Field Measurements. Correlation to Physico-Chemical Parameters and Near-Infrared Spectroscopy. Journal of Petroleum Science and Engineering, 36, 1-17. http://dx.doi.org/10.1016/S0920-4105(02)00247-4

[35] Miller, R.M., Singer, G.M., Rosen, J.D. and Bartha, R. (1988) Photolysis Primes Biodegradation of Benzo[a]pyrene. Applied and Environmental Microbiology, 54, 1724-1730.

[36] Atlas, R.M. (1991) Microbial Hydrocarbon Degradation-Bioremediation Oil Spills. Journal of Chemical Technology and Biotechnology, 52, 149-156. http://dx.doi.org/10.1002/jctb.280520202

[37] Cury, J.D.E.C. (2002) Atividade microbiana e diversidades metabólica e genética em solo de mangue contaminado com petróleo. Master Degree Dissertation, Universidade de São Paulo, São Paulo.

[38] Rodrigues, E.M., Kalks, K.H.M. and Tótola, M.R. (2015) Prospect, Isolation, and Characterization of Microorganisms for Potential Use in Cases of Oil Bioremediation along the Coast of Trindade Island, Brazil. Journal of Environmental Management, 156, 15-22. http://dx.doi.org/10.1016/j.jenvman.2015.03.016

[39] Brooks, J.M., Bernard, B.B., Sauer, T.C. and Abdel-Reheim, H. (1978) Environmental Aspects of a Well Blowout in the Gulf of Mexico. Environmental Science \& Technology, 12, 695-703. http://dx.doi.org/10.1021/es60142a013

[40] Leahy, J.G. and Colwell, R.R. (1990) Microbial Degradation of Hydrocarbons in the Environment. Microbiological Reviews, 54, 305-315.

[41] Ghazali, F.M., Rahman, R.N.Z.A., Salleh, A.B. and Basri, M. (2004) Biodegradation of Hydrocarbons in Soil by Microbial Consortium. International Biodeterioration \& Biodegradation, 54, 61-67. http://dx.doi.org/10.1016/j.ibiod.2004.02.002

[42] Xue, J., Yu, Y., Bai, Y., Wang, L. and Wu, Y. (2015) Marine Oil-Degrading Microorganisms and Biodegradation Process of Petroleum Hydrocarbon in Marine Environemts: A Review. Current Microbiology, 71, 220-228. http://dx.doi.org/10.1007/s00284-015-0825-7

[43] Colwell, R.R. and Walker, J.D. (1977) Ecological Aspects of Microbial Degradation of Petroleum in the Marine Environment. Critical Reviews in Microbiology, 5, 423-445. http://dx.doi.org/10.3109/10408417709102813

[44] Atlas, R.M. (1981) Microbial Degradation of Petroleum Hydrocarbons: An Environmental Perspective. Microbiologi- 
cal Reviews, 45, 180-209.

[45] Samanta, S.K., Singh, O.V. and Jain, R.K. (2002) Polycyclic Aromatic Hydrocarbons: Environmental Pollution and Bioremediation. Trends in Biotechnology, 20, 243-248. http://dx.doi.org/10.1016/S0167-7799(02)01943-1

[46] Hamme, J.D., Singh, A. and Ward, O.P. (2003) Recent Advances in Petroleum Microbiology. Microbiology and Molecular Biology Reviews, 67, 503-549. http://dx.doi.org/10.1128/MMBR.67.4.503-549.2003

[47] Ruberto, L., Vazquez, S.C. and Mac Cormack, W.P. (2003) Effectiveness of the Natural Bacterial Flora, Biostimulation and Bioaugmentation on the Bioremediation of a Hydrocarbon Contaminated Antarctic Soil. International Biodeterioration \& Biodegradation, 52, 115-125. http://dx.doi.org/10.1016/S0964-8305(03)00048-9

[48] Beal, R. and Betts, W.B. (2000) Role of Rhamnolipid Biosurfactants in the Uptake and Mineralization of Hexadecane in Pseudomonas aeruginosa. Journal of Applied Microbiology, 89, 158-168. http://dx.doi.org/10.1046/j.1365-2672.2000.01104.x

[49] Mulligan, C.N. (2005) Environmental Applications for Biosurfactants. Environmental Pollution, 133, 183-198. http://dx.doi.org/10.1016/j.envpol.2004.06.009

[50] Bordoloi, N.K. and Konwar, B.K. (2009) Bacterial Biosurfactant in Enhancing Solubility and Metabolism of Petroleum Hydrocarbons. Journal of Hazardous Materials, 170, 495-505. http://dx.doi.org/10.1016/j.jhazmat.2009.04.136

[51] Das, N. and Chandran, P. (2011) Microbial Degradation of Petroleum Hydrocarbon Contaminants: An Overview. Biotechnology Research International, 2011, Article ID: 941810. http://dx.doi.org/10.4061/2011/941810

[52] Nedwell, D. (1999) Effect of Low Temperature on Microbial Growth: Lowered Affinity for Substrates Limits Growth at Low Temperature. FEMS Microbiology Ecology, 30, 101-111. http://dx.doi.org/10.1111/j.1574-6941.1999.tb00639.x

[53] Coulon, F., Pelletier, E., Gourhant, L. and Delille, D. (2005) Effects of Nutrient and Temperature on Degradation of Petroleum Hydrocarbons in Contaminated Sub-Antarctic Soil. Chemosphere, 58, 1439-1448. http://dx.doi.org/10.1016/j.chemosphere.2004.10.007

[54] Eriksson, M., Sodersten, E., Yu, Z., Dalhammar, G. and Mohn, W.W. (2003) Degradation of Polycyclic Aromatic Hydrocarbons at Low Temperature under Aerobic and Nitrate-Reducing Conditions in Enrichment Cultures from Northern Soils. Applied and Environmental Microbiology, 69, 275-284. http://dx.doi.org/10.1128/AEM.69.1.275-284.2003

[55] Brakstad, O.G. and Bonaunet, K. (2006) Biodegradation of Petroleum Hydrocarbons in Seawater at Low Temperatures $\left(0-5{ }^{\circ} \mathrm{C}\right)$ and Bacterial Communities Associated with Degradation. Biodegradation, 17, 71-82. http://dx.doi.org/10.1007/s10532-005-3342-8

[56] Mateles, R.I, Baruah, J.N. and Tannenbaum, S.R. (1967) Growth of a Thermophilic Bacterium on Hydrocarbons: A New Source of Single-Cell Protein. Science, 157, 1322-1323. http://dx.doi.org/10.1126/science.157.3794.1322

[57] Moore, M.A.S. and Owen, J.J.T. (1967) Thermophilic Bacterium Isolated on n-Tetradecane. Nature, 215, $1082-1083$. http://dx.doi.org/10.1038/2151082a0

[58] Abbasian, F., Lockington, R., Mallavarapu, M. and Naidu, R. (2015) A Comprehensive Review of Aliphatic Hydrocarbon Biodegradation by Bacteria. Applied Biochemistry and Biotechnology, 176, 670-699. http://dx.doi.org/10.1007/s12010-015-1603-5

[59] Perry, J.J. (1979) Microbial Cooxidations Involving Hydrocarbons. Microbiological Reviews, 43, 59-72.

[60] Acevedo, G.T. and McInerney, M.J. (1996) Emulsifying Activity in Thermophilic and Extremely Thermophilic Microorganisms. Journal of Industrial Microbiology, 16, 1-7. http://dx.doi.org/10.1007/BF01569914

[61] Sarkar, D., Ferguson, M., Datta, R. and Birnbaum, S. (2005) Bioremediation of Petroleum Hydrocarbons in Contaminated Soils: Comparison of Biosolids Addition, Carbon Supplementation, and Monitored Natural Attenuation. Environmental Pollution, 136, 1871-1895. http://dx.doi.org/10.1016/j.envpol.2004.09.025

[62] Atlas, R.M. and Bartha, R. (1973) Stimulated Biodegradation of Oil Slicks Using Oleophilic Fertilizers. Environmental Science \& Technology, 7, 538-541. http://dx.doi.org/10.1021/es60078a005

[63] Tyagi, M., Fonseca, M.M.R. and Carvalho, C.C.C.R. (2011) Bioaugmentation and Biostimulation Strategies to Improve the Effectiveness of Bioremediation Processes. Biodegradation, 22, 231-241. http://dx.doi.org/10.1007/s10532-010-9394-4

[64] Floodgate, G.D. (1995) Some Environmental Aspects of Marine Hydrocarbon Bacteriology. Aquatic Microbial Ecology, 9, 3-11. http://dx.doi.org/10.3354/ame009003

[65] Widada, H.N., Kasuga, K. and Yo, T.J. (2002) Molecular Detection and Diversity of Polycyclic Aromatic Hydrocarbon-Degrading Bacteria Isolated from Geographically Diverse Sites. Applied Microbiology and Biotechnology, 58, 202-209. http://dx.doi.org/10.1007/s00253-001-0880-9

[66] Rodrigues, D.F., Sakata, S.K., Comasseto, J.V., Bícego, M.C. and Pellizari, V.H. (2009) Diversity of HydrocarbonDegrading Klebsiella Strains Isolated from Hydrocarbon-Contaminated Estuaries. Journal of Applied Microbiology, 
106, 1304-1314. http://dx.doi.org/10.1111/j.1365-2672.2008.04097.x

[67] Kostka, J.E., Prakash, O., Overholt, W.A., Green, S.J., Freyer, G., Canion, A., Delgardio, J., Norton, N., Hazen, T.C. and Huettel, M. (2011) Hydrocarbon-Degrading Bacteria and the Bacterial Community Response in Gulf of Mexico Beach Sands Impacted by the Deepwater Horizon Oil Spill. Applied and Environmental Microbiology, 77, $7962-7974$. http://dx.doi.org/10.1128/AEM.05402-11

[68] Habe, H. and Omori, T. (2003) Genetics of Polycyclic Aromatic Hydrocarbon Metabolism in Diverse Aerobic Bacteria. Bioscience, Biotechnology, and Biochemistry, 67, 225-243. http://dx.doi.org/10.1271/bbb.67.225

[69] Whitehead, A. (2013) Interactions between Oil-Spill Pollutants and Natural Stressors Can Compound Ecotoxicological Effects. Integrative and Comparative Biology, 53, 635-647. http://dx.doi.org/10.1093/icb/ict080

[70] Ramachandran, S.D., Hodson, P.V., Khan, C.W. and Lee, K. (2004) Oil Dispersant Increases PAH Uptake by Fish Exposed to Crude Oil. Ecotoxicology and Environmental Safety, 59, 300-308. http://dx.doi.org/10.1016/j.ecoenv.2003.08.018

[71] McCay, D.F., Rowe, J.J., Whittier, N., Sankaranarayanan, S. and Etkin, D.S. (2004) Estimation of Potential Impacts and Natural Resource Damages of Oil. Journal of Hazardous Materials, 107, 11-25. http://dx.doi.org/10.1016/j.jhazmat.2003.11.013

[72] GESAMP (1993) Joint Group of Experts on the Scientific Aspects of Marine Pollution. Impact of Oil and Related Chemicals and Wastes on the Marine Environment. GESAMP Reports and Studies, No. 50, London.

[73] Ritter, L., Solomon, K., Sibley, P., Hall, K., Keen, P., Mattu, G. and Linton, B. (2002) Sources, Pathways, and Relative Risks of Contaminants in Surface Water and Groundwater: A Perspective Prepared for the Walkerton Inquiry. Journal of Toxicology and Environmental Health, Part A, 65, 1-142. http://dx.doi.org/10.1080/152873902753338572

[74] La Rocca, C., Conti, L., Crebelli, R., Crochi, B., Iacovella, N., Rodriguez, F., Turrio-Baldassarri, L. and di Domenico, A. (1996) PAH Content and Mutagenicity of Marine Sediments from the Venice Lagoon. Ecotoxicology and Environmental Safety, 33, 236-245. http://dx.doi.org/10.1006/eesa.1996.0030

[75] Chen, G. and White, P.A. (2004) The Mutagenic Hazards of Aquatic Sediments: A Review. Mutation Research, 567, 151-225. http://dx.doi.org/10.1016/j.mrrev.2004.08.005

[76] Shimada, T. and Fujii-Kuriyama, Y. (2004) Metabolic Activation of Polycyclic Aromatic Hydrocarbons to Carcinogens by Cytochromes P450 1A1 and 1B1. Cancer Science, 95, 1-6. http://dx.doi.org/10.1111/j.1349-7006.2004.tb03162.x

[77] Mehdinia, A., Aghadadashi, V. and Fumani, N.S. (2015) Origin, Distribution and Toxicological Potential of Polycyclic Aromatic Hydrocarbons in Surface Sediments from the Bushehr Coast, The Persian Gulf. Marine Pollution Bulletin, 90, 334-338. http://dx.doi.org/10.1016/i.marpolbul.2014.09.021

[78] Bartha, R. (1986) Biotechnology of Petroleum Pollutant Biodegradation. Microbial Ecology, 12, 155-172. http://dx.doi.org/10.1007/BF02153231

[79] Chiou, C.T., Mcgroddy, S.E., Kile, D.E., Survey, U.S.G. and Federal, D. (1998) Partition Characteristics of Polycyclic Aromatic Hydrocarbons on Soils and Sediments. Environmental Science \& Technology, 32, 264-269. http://dx.doi.org/10.1021/es970614c

[80] Simpson, C.D., Mosi, A.A., Cullen, W.R. and Reimer, K.J. (1996) Composition and Distribution of Polycyclic Aromatic Hydrocarbon Contamination in Surficial Marine Sediments from Kitimat Harbor, Canada. Science of the Total Environment, 181, 265-278. http://dx.doi.org/10.1016/0048-9697(95)05026-4

[81] Reynaud, S. and Deschaux, P. (2006) The Effects of Polycyclic Aromatic Hydrocarbons on the Immune System of Fish: A Review. Aquatic Toxicology, 77, 229-238. http://dx.doi.org/10.1016/j.aquatox.2005.10.018

[82] Carls, M.G., Babcock, M.M., Harris, P.M., Irvine, G.V., Cusick, J.A. and Rice, S.D. (2001) Persistence of Oiling in Mussel Beds after the Exxon Valdez Oil Spill. Marine Environmental Research, 51, 167-190. http://dx.doi.org/10.1016/S0141-1136(00)00103-3

[83] Peterson (2001) The "Exxon Valdez" Oil Spill in Alaska: Acute, Indirect and Chronic Effects on the Ecosystem. Advances in Marine Biology, 39, 1-103. http://dx.doi.org/10.1016/s0065-2881(01)39008-9

[84] Peterson, C.H., Rice, S.D., Short, J.W., Esler, D., Bodkin, J.L., Ballachey, B.E. and Irons, D.B. (2003) Long-Term Ecosystem Response to the Exxon Valdez Oil Spill. Science, 302, 2082-2086. http://dx.doi.org/10.1126/science.1084282

[85] Alonso-Alvarez, C., Pérez, C. and Velando, A. (2007) Effects of Acute Exposure to Heavy Fuel Oil from the Prestige Spill on a Seabird. Aquatic Toxicology, 84, 103-110. http://dx.doi.org/10.1016/j.aquatox.2007.06.004

[86] Engelhardt, F.R. (1983) Petroleum Effects on Marine Mammals. Aquatic Toxicology, 4, 199-217. http://dx.doi.org/10.1016/0166-445X(83)90018-8 
[87] Bao, M.T., Wang, L.N., Sun, P.Y., Cao, L.X., Zou, J. and Li, Y.M. (2012) Biodegradation of Crude Oil Using an Efficient Microbial Consortium in a Simulated Marine Environment. Marine Pollution Bulletin, 64, 1177-1185. http://dx.doi.org/10.1016/j.marpolbul.2012.03.020

[88] Khan, F.I., Husain, T. and Hejazi, R. (2004) An Overview and Analysis of Site Remediation Technologies. Journal of Environmental Management, 71, 95-122. http://dx.doi.org/10.1016/j.jenvman.2004.02.003

[89] Aburto-Medina, A., Adetutu, E.M., Aleer, S., Weber, J., Patil, S.S., Sheppard, P.J., Ball, A.S. and Juhasz, A.L. (2015) Comparison of Indigenous and Exogenous Microbial Populations during Slurry Phase Biodegradation of Long-Term Hydrocarbon-Contaminated Soil. Biodegradation, 23, 813-822. http://dx.doi.org/10.1007/s10532-012-9563-8

[90] Harayama, S., Kishira, H., Kasai, Y. and Shutsubo, K. (1999) Petroleum Biodegradation in Marine Environments. Journal of Molecular Microbiology and Biotechnology, 1, 63-70.

[91] Murado, M.A., Vázquez, J.A., Rial, D. and Beiras, R. (2011) Dose-Response Modelling with Two Agents: Application to the Bioassay of Oil and Shoreline Cleaning Agents. Journal of Hazardous Materials, 185, 807-817. http://dx.doi.org/10.1016/j.jhazmat.2010.09.092

[92] Fucik, K.W. and Carr, K.A. (1994) Dispersed Oil Toxicity Tests with Biological Species Indigenous to the Gulf of Mexico. Continental Shelf Associates, Inc., US Department of the Interior, New Orleans.

[93] Beiras, E.H.R., Seaman, M.N.L. and France, A. (1999) The Assessment of Marine Pollution. Bioassays with Bivalve Embryos and Larvae. Advances in Marine Biology, 37, 1-178. http://dx.doi.org/10.1016/S0065-2881(08)60428-9

[94] Gundersen, D.T., Kristanto, S.W., Curtis, L.R., Al-Yakoob, S.N., Metwally, M.M. and Al-Ajmi, D. (1996) Subacute Toxicity of the Water-Soluble Fractions of Kuwait Crude Oil and Partially Combusted Crude Oil on Menidia beryllina and Palaemonetes pugio. Archives of Environmental Contamination and Toxicology, 31, 1-8. http://dx.doi.org/10.1007/BF00203901

[95] Blenkinsopp, S.A., Sergy, G., Wohlgeschaffent, K.D.O.E.G. and Li, K. (1997) Toxicity of the Weathered Crude Oil Used at the Newfoundland Offshore Burn Experiment (NOBE) and the Resultant Burn Residue. Spill Science \& Technology Bulletin, 3, 277-280. http://dx.doi.org/10.1016/S1353-2561(97)00028-5

[96] Wolfe, M.F., Schwartz, G.J.B., Singaram, S. and Mielbrecht, E.E. (1999) Influence of Dispersants on the Bioavailability and Trophic Transfer of Phenanthrene to Algae and Rotifers. Aquatic Toxicology, 48, 13-24. http://dx.doi.org/10.1016/S0166-445X(99)00028-4

[97] Zhu, X., Venosa, A.D., Suidan, M.T. and Lee, K. (2001) Guidelines for the Bioremediation of Marine Shorelines and Freshwater Wetlands. US Environmental Protection Agency, Cincinnati.

[98] Cantagallo, C., Milanelli, J.C.C. and Dias-Brito, D. (2007) Limpeza de ambientes costeiros brasileiros contaminados por petróleo: Uma revisão. Pan-American Journal of Aquatic Sciences, 2, 1-12.

[99] Patrick, A., Craig, D.L., Sena, E., Magalhães, L. and Canielas, M. (2012) Técnicas de limpeza de vazamentos de petroleo em alto mar. Cadernos de Graduação-Ciências Exatas e Tecnológicas, 1, 75-86.

[100] Lessard, R.R. and Demarco, G. (2000) The Significance of Oil Spill Dispersants. Spill Science \& Technology Bulletin, 6, 59-68. http://dx.doi.org/10.1016/S1353-2561(99)00061-4

[101] Atlas, R.M. and Hazen, T.C. (2011) Oil Biodegradation and Bioremediation: A Tale of the Two Worst Spills in U.S. History. Environmental Science \& Technology, 45, 6709-6715. http://dx.doi.org/10.1021/es2013227

[102] El Fantroussi, S. and Agathos, S.N. (2005) Is Bioaugmentation a Feasible Strategy for Pollutant Removal and Site Remediation? Current Opinion in Microbiology, 8, 268-275. http://dx.doi.org/10.1021/es2013227

[103] Al-Saleh, E. and Akbar, A. (2015) Occurrence of Pseudomonas aeruginosa in Kuwait Soil. Chemosphere, 120, 100107. http://dx.doi.org/10.1016/j.chemosphere.2014.06.031

[104] Yu, K.S.H., Wong, A.H.Y., Yau, K.W.Y., Wong, Y.S. and Tam, N.F.Y. (2005) Natural Attenuation, Biostimulation and Bioaugmentation on Biodegradation of Polycyclic Aromatic Hydrocarbons (PAHs) in Mangrove Sediments. Marine Pollution Bulletin, 51, 1071-1077. http://dx.doi.org/10.1016/j.marpolbul.2005.06.006

[105] Iwamoto, T. and Nasu, M. (2001) Current Bioremediation Practice and Perspective. Journal of Bioscience and Bioengineering, 92, 1-8. http://dx.doi.org/10.1016/S1389-1723(01)80190-0

[106] Xia, W.X., Li, J.C., Zheng, X.L., Bi, X.J. and Shao, J.L. (2006) Enhanced Biodegradation of Diesel Oil in Seawater Supplemented with Nutrients. Engineering in Life Sciences, 6, 80-85. http://dx.doi.org/10.1002/elsc.200620113

[107] Zahed, M.A., Aziz, H.A., Isa, M.H. and Mohajeri, L. (2010) Enhancement Biodegradation of n-Alkanes from Crude Oil Contaminated Seawater. International Journal of Environmental Research, 4, 655-664.

[108] Nikolopoulou, M., Eickenbusch, P., Pasadakis, N., Venieri, D. and Kalogerakis, N. (2013) Microcosm Evaluation of Autochthonous Bioaugmentation to Combat Marine Oil Spills. New Biotechnology, 30, 734-742. http://dx.doi.org/10.1016/j.nbt.2013.06.005

[109] National Research Council (1994) Alternatives for Ground Water Cleanup. National Academy Press, Washington DC. 
[110] Pezeshki, S.R., Hester, M.W., Lin, Q. and Nyman, J.A. (2000) The Effects of Oil Spill and Clean-Up on Dominant US Gulf Coast Marsh Macrophytes: A Review. Environmental Pollution, 108, 129-139. http://dx.doi.org/10.1016/S0269-7491(99)00244-4

[111] Hambrick, G.A., Delaune, R.D. and Patrick, W.H. (1980) Effect of Estuarine Sediment pH and Oxidation-Reduction Potential on Microbial Hydrocarbon Degradation. Applied and Environmental Microbiology, 40, 365-369.

[112] Atlas, R.M. (1995) Petroleum Biodegradation and Oil Spill Bioremediation. Marine Pollution Bulletin, 31, $178-182$. http://dx.doi.org/10.1016/0025-326X(95)00113-2

[113] Krumbolz, L.R., Caldwell, M.E. and Suflita, J.M. (1996) Biodegradation of "BTEX" Hydrocarbons under Anaerobic Conditions. In: Crawford, R.L. and Crawford, D.L., Eds., Bioremediation: Principles and Applications, Cambridge University Press, New York, 61-99. http://dx.doi.org/10.1017/CBO9780511608414.005

[114] Táncsics, A., Szoboszlay, S., Szabó, I., Farkas, M., Kovács, B., Kukolya, J., Mayer, Z. and Kriszt, B. (2012) Quantification of Subfamily I.2.C Catechol 2,3-Dioxygenase mRNA Transcripts in Groundwater Samples of an Oxygen-Limited BTEX-Contaminated Site. Environmental Science \& Technology, 46, 232-240. http://dx.doi.org/10.1021/es201842h

[115] Gallego, J.R., González-Rojas, E., Peláez, A.I., Sánchez, J., García-Martínez, M.J., Ortiz, J.E., Torres, T. and Llamas, J.F. (2006) Natural Attenuation and Bioremediation of Prestige Fuel Oil along the Atlantic Coast of Galicia (Spain). Organic Geochemistry, 37, 1869-1884. http://dx.doi.org/10.1016/j.orggeochem.2006.07.022

[116] McKew, B.A., Coulon, F., Yakimov, M.M., Denaro, R., Genovese, M., Smith, C.J., Osborn, A.M., Timmis, K.N. and McGenity, T.J. (2007) Efficacy of Intervention Strategies for Bioremediation of Crude Oil in Marine Systems and Effects on Indigenous Hydrocarbonoclastic Bacteria. Environmental Microbiology, 9, 1562-1571. http://dx.doi.org/10.1111/j.1462-2920.2007.01277.x

[117] Rahman, K.S.M., Thahira-Rahman, J., Lakshmanaperumalsamy, P. and Banat, I.M. (2002) Towards Efficient Crude Oil Degradation by a Mixed Bacterial Consortium. Bioresource Technology, 85, 257-261. http://dx.doi.org/10.1016/S0960-8524(02)00119-0

[118] Nyer, E.K., Pauyne, F. and Sutherson, S. (2003) Discussion od Environment vs. Bacteria or Let's Play "Name tha Bacteria". Biotechnology and Bioengineering, 23, 36-45.

[119] Mnif, I., Mnif, S., Sahnoun, R., Martouf, S., Ayedi, Y., Ellouze-Chaabouni, S. and Ghribi, D. (2015) Biodegradation of Diesel Oil by a Novel Microbial Consortium: Comparison between Co-Inoculation with Biosurfactants-Producing Strain and Exogenously Added Biosurfactants. Environmental Science and Pollution Research, 22, 14852-14861. http://dx.doi.org/10.1007/s11356-015-4488-5

[120] Roane, T.M., Josephson, K.L. and Pepper, I.L. (2001) Dual-Bioaugmentation Strategy to Enhance Remediation of Cocontaminated Soil Dual-Bioaugmentation Strategy to Enhance Remediation of Cocontaminated Soil. Applied and Environmental Microbiology, 67, 3208-3215. http://dx.doi.org/10.1128/AEM.67.7.3208-3215.2001

[121] Van Veen, J.A., Van Overbeek, L.S. and Van Elsas, J.D. (1997) Fate and Activity of Microorganisms Introduced into Soil. Microbiology and Molecular Biology Reviews, 61, 121-135.

[122] Adams, G.O., Fufeyim, P.T., Okoro, S.E. and Ehinomen, I. (2015) Bioremediation, Biostimulation and Bioaugmention: A Review. International Journal of Environmental Bioremediation \& Biodegradation, 3, 28-29.

[123] Gentry, T., Rensing, C. and Pepper, I. (2004) New Approaches for Bioaugmentation as a Remediation Technology. Critical Reviews in Environmental Science and Technology, 34, 447-494. http://dx.doi.org/10.1080/10643380490452362

[124] Goldstein, R.M., Mallory, L.M. and Alexander, M. (1985) Reasons for Possible Failure of Inoculation to Enhance Biodegradation. Applied and Environmental Microbiology, 50, 977-983.

[125] Orcutt, B.N., Joye, S.B., Kleindienst, S., Knittel, K., Ramette, A., Reitz, A., Samarkin, V., Treude, T. and Boetius, A. (2010) Impact of Natural Oil and Higher Hydrocarbons on Microbial Diversity, Distribution, and Activity in Gulf of Mexico Cold-Seep Sediments. Deep Sea Research Part II: Topical Studies in Oceanography, 57, 2008-2021. http://dx.doi.org/10.1016/j.dsr2.2010.05.014

[126] Thavasi, R., Jayalakshmi, S. and Banat, I.M. (2011) Effect of Biosurfactant and Fertilizer on Biodegradation of Crude Oil by Marine Isolates of Bacillus megaterium, Corynebacterium kutscheri and Pseudomonas aeruginosa. Bioresource Technology, 102, 772-778. http://dx.doi.org/10.1016/j.biortech.2010.08.099

[127] Ron, E.Z. and Rosenberg, E. (2014) Enhanced Bioremediation of Oil Spills in the Sea. Current Opinion in Biotechnology, 27, 191-194. http://dx.doi.org/10.1016/j.copbio.2014.02.004

[128] Venosa, A.D., Campo, P. and Suidan, M.T. (2010) Biodegradability of Lingering Crude Oil 19 Years after the Exxon Valdez Oil Spill. Environmental Science \& Technology, 44, 7613-7621. http://dx.doi.org/10.1021/es101042h

[129] Nikolopoulou, M. and Kalogerakis, N. (2009) Biostimulation Strategies for Fresh and Chronically Polluted Marine Environments with Petroleum Hydrocarbons. Journal of Chemical Technology and Biotechnology, 84, 802-807. 
http://dx.doi.org/10.1002/jctb.2182

[130] Lubchenco, J., McNutt, M., Lehr, B., Sogge, M., Miller, M., Hammond, S. and Conner, W. (2010) Deepwater Horizon/BP Oil Budget: What Happened to the Oil? Oil Budget Calculator Science and Engineering Team (US), Washington DC.

[131] Tate, P.T., Shin, W.S., Pardue, J.H. and Jackson, W.A. (2011) Bioremediation of an Experimental Oil Spill in a Coastal Louisiana Salt Marsh. Water, Air, \& Soil Pollution, 223, 1115-1123. http://dx.doi.org/10.1007/s11270-011-0929-Z

[132] Warr, L.N., Friese, A., Schwarz, F., Schauer, F., Portier, R.J., Basirico, L.M. and Olson, G.M. (2013) Bioremediating Oil Spills in Nutrient Poor Ocean Water Using Fertilized Clay Mineral Flakes: Some Experimental Constraints. Biotechnology Research International, 2013, Article ID: 704806. http://dx.doi.org/10.1155/2013/704806

[133] Lindstrom, J.E., Prince, R.C., Clark, J.C., Grossman, M.J., Yeager, T.R., Braddock, J.F. and Brown, E.J. (1991) Microbial Populations and Hydrocarbon Biodegradation Potentials in Fertilized Shoreline Sediments Affected by the T/V Exxon Valdez Oil Spill. Applied and Environmental Microbiology, 57, 2514-2522.

[134] Crawford, M. (1990) Bacteria Effective in Alaska Cleanup. Science, 247, 1537. http://dx.doi.org/10.1126/science.2321011

[135] Pritchard, P.H., Mueller, J.G., Rogers, J.C., Kremer, F.V. and Glaser, J.A. (1992) Oil Spill Bioremediation: Experiences, Lessons and Results from the Exxon Valdez Oil Spill in Alaska. Biodegradation, 3, 315-335. http://dx.doi.org/10.1007/BF00129091

[136] Button, D.K., Robertson, B.R., McIntosh, D. and Jüttner, F. (1992) Interactions between Marine Bacteria and Dissolved-Phase and Beached Hydrocarbons after the Exxon Valdez Oil Spill. Applied and Environmental Microbiology, 58, 243-251.

[137] Koren, O., Knezevic, V., Ron, E.Z. and Rosenberg, E. (2003) Petroleum Pollution Bioremediation Using Water-Insoluble Uric Acid as the Nitrogen Source Petroleum Pollution Bioremediation Using Water-Insoluble Uric Acid as the Nitrogen Source. Applied and Environmental Microbiology, 69, 6337-6339. http://dx.doi.org/10.1128/AEM.69.10.6337-6339.2003

[138] Nikolopoulou, M. and Kalogerakis, N. (2008) Enhanced Bioremediation of Crude Oil Utilizing Lipophilic Fertilizers Combined with Biosurfactants and Molasses. Marine Pollution Bulletin, 56, 1855-1861. http://dx.doi.org/10.1016/j.marpolbul.2008.07.021 